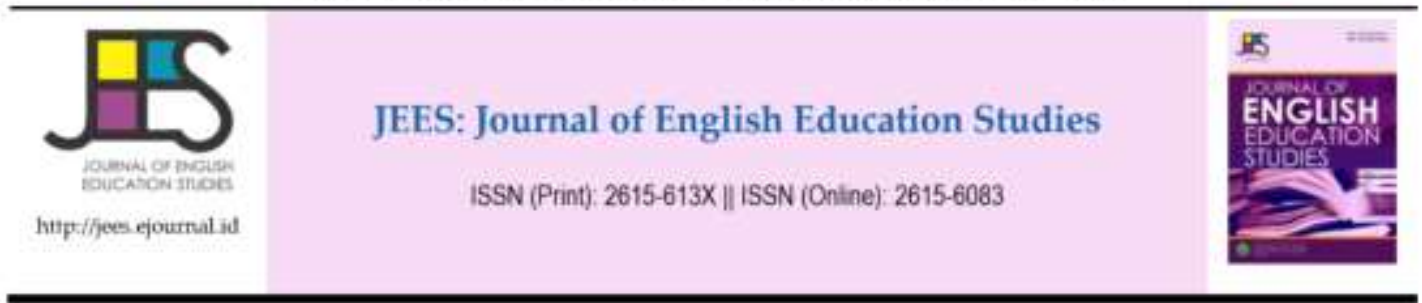

\title{
An Analysis of Learning English Vocabulary for Hearing Impaired Student at Dharma Bhakti Dharma Pertiwi Special School 2017/2018
}

\author{
Indah Retno Puri ${ }^{1}$, Rodiatun Rodiatun ${ }^{2}$, Susanto Susanto ${ }^{3}$ \\ ${ }^{1}$ Department of English Education, Universitas Bandar Lampung, ${ }^{2}$ Department of English Education, Universitas Bandar Lampung, \\ ${ }^{3}$ Department of English Education, Universitas Bandar Lampung

\section{ARTICLE INFO}

\section{Keywords:} \\ Hearing Impaired, \\ Students' Learning \\ techniques, Learning \\ Vocabulary

\begin{abstract}
This study aimed to discover the hearing impaired students techniques in learning English vocabulary. The hearing impaired students learned mostly differently with normal people in acquiring meaning of words. The data were acquired qualitatively. The instruments used was observation and interview at the tenth grade of hearing impaired students at Dharma Bhakti Dharma Pertiwi Special School. The result showed the various techniques used by the hearing impaired students in conclusion, the techniques used by the students was totally different for each students depending on the rest of their hearing sense.
\end{abstract}

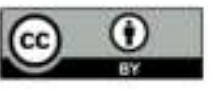

This is an open access article distnibuted under the terms of the Crestive Cornmons Atribution 40 intornotional Liognse, which permits uncestricted use, distribution, and reproduction in any medum, provided the original work is property cited o 2019 Indah Retno Pun. Rodiatun, Susanto

\section{INTRODUCTION}

In Indonesia, hearing impaired people are minority group with specific language and culture. They have two possibilities to get their education. The first one is they may to attend to school specialized with the same case or they may attend to normal school. The decision depends on the students or parents. Normally, the hearing impaired students learn in a special school with type "B". Although the deaf learn in special school, they have same subjects as the normal students such as mathematic, art, natural science, social science, English, civic education and English.

The subjects they learn are actually same with normal students but the techniques they use in learning are totally different, in acquiring the meaning of word especially in learning English vocabulary is different from the normal students. However they can do some possible things to learn English like normal students such as using hearing aid. Using hearing aid, they actually receive limited sounds therefore it doesn't guarantee to hear all the sounds. The best ways to learn English by using sign language.

\footnotetext{
${ }^{1}$ Corresponding author's address: Department of English Education, Universitas Bandar Lampung, Bandar Lampung, Indonesia e-mail: indahrtn97@gmail.com

${ }^{2}$ Corresponding author's address: Department of English Education, Universitas Bandar Lampung, Bandar Lampung, Indonesia e-mail: rodiatun.16611014@student.ubl.ac.id

${ }^{3}$ Corresponding author's address: Department of English Education, Universitas Bandar Lampung, Bandar Lampung, Indonesia e-mail: susanto@ubl.ac.id
} 
Based on Merriam Webster online dictionary, "(1) sign language is formal language employing a system of hand gestures for communication (as by the deaf), (2) an unsystematic method of communicating chiefly by manual gestures used by people speaking different language. Based on my experience in the school I found some interesting things about how they learn English vocabulary such as, the students could not understand word without real examples and the vocabulary they learned based on the English word that existed in public places or in their daily life. So their English vocabulary developed very slowly.

When I did my internship in the school when they learn vocabulary and when they learn sign language. The way they learn English vocabularies motivates me to investigate how their acquired English words.

\section{LITERATURE REVIEW}

Learning English

In Indonesia, learning English as one of the subjects in all level school even though English as foreign language. For learning English language there are a period time or age for people as said as critical period. Lenneberg (1967: 116) said: "There was a neurologically based critical period which complete mastery of language, but it is no longer possible, because it will and around the onset of puberty." In learning language the age of the people relates their ability to acquire language. However, the age cannot determine the success of the people in learning a language. Actually depends on many aspects such as the methodology of learning language and motivation.

\section{Vocabulary}

In order to learn language, vocabulary is very important as the unit for mentioning something. There are so many definitions about vocabulary such as:

Based on Penny (1991: 60) "Vocabulary can be defined, roughly, as the words we teach in the foreign language". It means, vocabulary as the material for lecturing somebody to learn foreign language.

Meanwhile, Barnhart (2008: 697) said that "vocabulary is (1) stock of words used by person, class of people, profession, etc. (2) a collection or list of words, usually in alphabetical order and defined". The definition means that vocabulary as the provision of words that someone use to communicate and it can be used in class people, profession and so on. And also the vocabulary arrange in alphabetical.

In addition, for Merriam-webster online dictionary (2017) vocabulary is:

1. "A list or collection of words or of words and phrases usually alphabetically arranged and explained or defined: lexicon.

2. A sum or stock of words employed by a language, group, individual, or work or codes available for use (as in an indexing system).

3. A supply of expressive techniques or devices (as of an art form)".

From the definitions above, it can be concluded that vocabulary is a collection of words or phrases usually arranged in sequence and translated (defined).

\section{Hearing Impairment}

Hearing is one of the five senses that allow us to perceive sound. From hearing we can acquire words without reading text that is the way a baby learn language. normally the people learn from imitating 
the sounds but not all human have the opportunity to hear, there is minority which where the human cannot hear well or hearing impairment.

Based on Williams in a website www.study.com "hearing impairment or hearing loss, occurs when you lose part or all of your ability to hear. Other terms that are used refer to hearing impairment are deaf and hard of hearing"

Hearing impairments are classified in terms of the severity and type of hearing impairment. The severity of hearing impairment is categorized based on the minimum sound that can be heard with your ear. The higher and decibel $(\mathrm{dB})$, the louder of the sound.

There are four types of hearing impairment such as mild hearing impairment, moderate hearing impairment, severe hearing impairment, and profound hearing impairment.

- Mild hearing impairment can receive the minimum sound between 25 and $40 \mathrm{~dB}$. People at this level cannot hear soft noises and may have trouble following conversations in noisy setting.

- Moderate hearing impairment can receive the minimum sound between 40 to $70 \mathrm{~dB}$. People at this level cannot hear soft or moderately loud noises and may have trouble hearing unless they use a hearing aid.

- Severe hearing impairment can receive the minimum sound between 70 and $95 \mathrm{~dB}$. People at this level are unable to hear most noises and may rely on lip -reading and/or sign language, even they use of hearing aid.

- Profound hearing impairment can receive the minimum sound between $95 \mathrm{~dB}$ and over. People at this level may only hear very loud noises and rely solely on lip reading and/or sign language and the used of hearing aid is not effective.

Three types of hearing impairment based on hearingloss.org such as conducting hearing loss, sensorineural hearing loss, mixed hearing loss.

- Conductive hearing loss - when hearing loss is due to problems with the ear canal, ear drum, or middle ear and its little bones (the malleus, incus, and stapes).

- Sensorineural hearing loss (SNHL) - when hearing loss is due to problems of the inner ear, also known as nerve-related hearing loss.

- Mixed hearing loss - refers to a combination of conductive and sensorinueral hearing loss. This means that there may be damage in outer or middle ear and in the inner ear (cochlea) or auditory nerve.

Based on the Indonesian Department of Education and Culture (1985: 23), the following are the possible causes of hearing impairment:

a. Before the child is born or still in the womb (prenatal period)

b. At the time of birth and new birth (neo natal)

c. After child is born (post natal)

Every causes mentioned above can be the factor of deafness. The first cause, the prenatal period is if something happened in the baby in a womb for instance the mother that consume minimum food and cause the baby less of nutrition. In neo natal period, there is something caused the deafness while the baby born such as the failure from doctor harms the baby accidentally or the condition of the mother that caused harm to the baby. The last one is in the post natal, most of this case happen when a person in a childhood suffers from over fever and caused the hearing sense cannot work well. 


\section{Hearing Impaired Students in Learning English Vocabularies}

Hearing impaired students learn English in different way. If normal students can follow what they are listening to and imitating it easily, the hearing impaired student cannot receive sounds in their environment. Sounds are important to receive the speech code to develop vocabularies in mind. But the students with hearing impairment cannot listen and communicate orally. For them, one of the ways is using a sign language.

According to Fromkin et.al (2003:265) the research on sign language can "support an idea that human was born with the ability to acquire language and the language itself is leaded with the same universal characteristic". For learning English, the hearing impaired students can learn English as well as the normal students but, they still have limitation to develop their speaking and listening activity. The hearing impaired students can learn English vocabularies through writing and reading skill.

I add some related studies, the first is a journal "Deaf students learning English as a foreign language" by Hoferková mentioned about theories such as considering the origin of sign language Stokoe (2005) stated, "The kinesthetic, or more broadly, the metalinguistic communicative phenomena out of which the primary communicative patterns of the deaf are built may once have been the prime phenomena, with vocal sounds a very minor part of the complex". Stokoe (2005) emphasizes the obvious effect on social grouping when the role of a common language is considered and he said, "when the difference is not between dialects or languages but between having or lacking language, the effect is enormously intensified". Therefore Stokoe mentioned that there are records of ways communicatively more acceptable by society which have been applied in teaching the deaf from birth in order to communicate. These ways include reading and writing, manually spelling out language, lipreadingand artificially acquired speech.

The second journal by Marscharket el (2016) entitled Don't Assume Deaf Students Are Visual Learners. This journal indicated that the hearing impaired students are no more able likely than hearing students to be visual learners and are no stronger in their visual skills and habits with sign language skills.

The third journal by Susanto and Nanda (2018) entitled "Teaching and Learning English for Visually Impaired Students: An Ethnographic Case Study". This research discussed on the teaching and learning of English at school of impaired students. This was not exactly same with my research because I observed about hearing impaired students but both the researchers' and mine talked about learning technique used by the students in learning English. The differences were about the media used as they had the differences in needs.

\section{METHODOLOGY}

This research is qualitative case study. It describes based on the case study that I investigated in Dharma Bhakti Dharma Pertiwi special school. it is based on what Cresswell (2006) p. 73 said "case study research is a qualitative approach in which the investigator explore the bounded system (a case) or multiple bounded systems (cases) over time through detailed, in - depth data collection involving multiple sources of information and reports case description and case-based themes". The types of case study used in this study was intrinsic case study, in which the focus is on the case itself (e.g., evaluating a program, or studying a student having difficulty, Stake, 1995) because the case presents an unusual or unique situation. Moleong (2007) defines that "qualitative research is a study that intends to understand the phenomenon of what is experienced by the research subjects such as 
behaviour, perception". According to Cresswell, 2007, (p.73) I used two ways to conducting this research. First, I observed and recorded all phenomena in the class and second, I interviewed the teacher about how the students learn English vocabulary. The transcription of the observation and teacher's respond to the interview questions became the primary data. Finally, all of the data will be analyzed and described based on the problems of the research.

As the data source for this research, I took the observation at the tenth grade of hearing impaired students in Dharma Bhakti Dharma Pertiwi Special School Bandar Lampung. There were seven students in the class, consisting of four girls and three boys. They took English subject to improve their ability in English skill. They just learned simple English words which are regularly used in their daily life. They have been learning English 10 years from elementary school, junior high school until senior high school right now. However, they are still confused in pronouncing the words.

I identified the research problems. There were some general problem appeared when this research would be conducted. In order to find the problems, I reviewed on some literature that is suitable with the topic to get more information about the problems. After that, I identified the research questions that become the baseline in doing this research. After reviewing all of the theories, I began to collect the data based on the method used in this research. There were identifying the participants and the place for doing this research, getting permission from the school in doing this research, deciding the instruments for collecting the data, finally choosing the way in analyzing the data after all of them were gathered by me.

The data were collected by using two instruments. First, observation which was I took a role as nonparticipant observer. Cresswell (2012, p.214) stated that "A non participant observer is an observer who visits a site and records notes without becoming involved in the activities of the participants. The nonparticipant observer is an "outsider" who sits on the periphery or some advantageous place to watch and record the phenomenon under study." As a non-participant I was not involved in the classroom activities. I just observed the learning process, especially the ways of the students learned English vocabulary. The last was interviewing the teacher to get more information about how they learn English vocabulary and problems they faced during learning activity. I did one on one interview by meeting the teacher personally. The question consisted of nine questions in form of open ended question. Finally all the data from the observation and interview was analysed, and the result will be reported.

To analyse the data, I transcribed the observation first. Transcription was the process of converting audiotype/ video recordings into text data (Cresswell, 2012, p. 239). The observation is conducted by 2 meetings. It means I need to transcribe all the phenomena in the classroom related to the formulation problem. After that I also transcribed the interview. I make some coding to analyse the interview. Cresswel (2012, p. 234) coding is the process of dividing and labelling text to form descriptions and broad themes in the data. Coding will be helpful in making conclusion from the data analysis. After that, I will summarize in detail the findings from the data analysis. After analyzing observation and interview data, finally the conclusion will be formulated in order to present the general result of the research. 


\section{RESULT AND DISSCUSSION}

In the first day of the observation, I started to enter the tenth grade of hearing impaired class. I sat in front of the teacher's table to observe how the students learn English vocabulary. Here the students pray through speaking not using sign language, they followed the teacher's lip movement. Then there was a student who came late, she is MN. She came late because there was a problem on her motorcycle. The teacher brought that case as a discussion in the class, the teacher gave the right sentence to all students because MN used sign language then, the teacher wrote the right sentence on whiteboard. There were Indonesian vocabularies thought by the teacher such as, januari, terlambat, ban, pecah. All the students tried to pronounce the word. They could not pronounce it well, then the teacher gave some stimulation through lip movement and also sign language.

During the lesson, the students asked by the teacher to write vocabularies learned in the first day for example, computer, monitor, keyboard, printer, scan, and flashdisk. After that, the students tried to pronounce those words. To pronounce the first word "Computer" the students did lip reading. They look at the teacher's lip movement when articulated the word.

To summarise the result of students' pronunciation in the first day, I can describe that the words "Computer, Monitor" can be pronounced by all students. A word "Keyboard" can be pronounced by 5 from 7 students. A word "Printer" can be pronounced by 5 from 7 students. A word "Scan" can be pronounced by 3 from 7 students. A word "Flash Disk" can be pronounced by 2 from 7 students. The next word "Compact disk" can be pronounced by 4 from 7 students. The last word "Laptop" can be pronounced by 6 from 7 students.

In the second observation I also came into the same class as well as the first observation. There were 5 students who came, they are TS, MN, RZ, RD, and RG. The teacher gave the students two words "a pen" and "a book". The students did not write the vocabulary, they just read the words on the white board. Next, the teacher gave lip articulation to the students in case to make students could read it by doing lip reading.

To summarise the students achievement in the second day of the observation, I can state that to pronounce a word "a pen" there were none of 5 students could say that word well and to pronounce the word "a book" one of 5 students could say this word well.

From the two observations, it can be discussed that the way of the hearing impaired students to know English vocabulary for the first time was reading. Reading is a process that is dependent on the language that provides the basis of the writing system, especially during the early stages of acquisition (Perfetti and Sandak, 2000). There were two kinds of reading used by the students, they are reading text and speech reading or lip reading. The term of "lipreading" refers to the "fact of seeing in the mouth of the person who is talking to us the word that we should normally hear" (Cecilia Tejedor, 2000, p. 20). The students did lip reading to acquire English word. Although they still made mistakes to understand the teacher's lip articulation, it is known when they learned new word "computer" in the first observation, there were two possible thing to pronounce the syllable of "com" it could be $/ \mathrm{t} \mathrm{jm} /$ or $/ \mathrm{kom} /$. It happened to TS. At the first time she followed the teacher's lip movement and pronounce $/ \mathfrak{5} 5 \mathrm{~m} /$. It means, they have different way and understanding to learn 
English vocabulary even the students have different abilities such as the way of active or passive students, as said in the teacher's interview

"It is similar to general school in order to be active or passive students, but there are some conditions that the teacher should understand and common people. The hearing impaired students have different hearing sense ability, so if their hearing ability are different, the service given by teacher also different. If normal students will hear what the teacher says, the hearing impaired will be different. They will not understand directly, even though the teacher says for several times. They have a little of the rest of hearing sense" (interview-SH10)

TS in order to pronounce that word properly, she may need other stimulation such as shaping fingerspelling to understand more about the word they tried to learn. TS at the first time failed in pronouncing a syllable of "kom". After the teacher shaping fingerspelling a letter " $\mathrm{k}$ ", she could follow the pronunciation became /kom:/. She needs time to pronounce one syllable by using a few steps. As what the teacher said in the interview "The students learn with different ways, it means each student have their own ways. To learn English vocabularies, I should give different stimulation to each students such as giving know where the sounds come out for instance, from nose, parts of inside the mouth, lips or others. The aim to do that is to make it more detail" (interview-SH14) and also Antia and Levine (2001) they said point out that learning a spoken language tends to be slow process for the deaf. As the consequence, their spoken language developments are usually delayed when compared to hearing children (Blamey, 2003).

\section{CONCLUSION}

Based on the finding and discussion previously, it is found that in the first day of the observation, the students to acquire language by writing. The aim of writing is to stimulate their mind to know what word they will learn. They would spell the letters for the English word. Then they joined all the sound to have the meaning by doing that repeatedly, finally were able to pronounce the word. If some students did not catch the word, the students did lip reading by following teacher's lip movement. They also used sign language to determine the word pronounced by the teacher such as when the teacher said "computer" their hands would make shape of fingerspelling. Some of them can learn the word by doing lip reading, however the other still need other stimulation such as sensing the sounds. It means the teacher also gave them stimulation such as in pronouncing "Flashdisk" using paper to blow it with the air while we are pronouncing word "flash" and then by touching under the teacher'schin. It is to know the articulation to release the sound of word "disk".

In the second observation, I can state that they indeed had different ability to speak. Eventhough they pronounce the same word, still they produced the pronunciation in different sounds. For instance, to pronounce "a book" some of them pronounced it /i:bv:/. They also received sensing stimulation by touching under the teacher's chin to feel the sounds came out in the mouth. There are some ways for hearing impaired students at tenth grade of Dharma Bhakti Dharma Pertiwi special school to learn English vocabulary visually, they are reading the text or speech reading/lip reading, writing, using sign language especially shaping fingerspelling and mostly using speaking skill. 


\section{REFERENCES}

Antia SD, Levine LM. Guratnick MJ. Educating Deaf and Heraing Children Together: Confronting the Challenger of Inclussion, Early Childhood Inclusion: Focus on Change, 2001 Baltimore, MDPaul H. Brookes (Pg. 365 - 398)

Blamey PJ, Marshcark M, Spencer P. Development of Spoken Language by Deaf Children, the Oxford Handbook of Deaf Studies, Language and Education. 2003. New York Oxford University Press (Pg. 232 - 246)

Cresswell, J. (2014). Research Design; Qualitative, Quantitative, and Mixed Methods Approaches. Thousand Oaks, California: Sage Piblication, Inc. Education Lable. (2011, August).

Learning Achievement [Blog post]. Retrieved from http://educations90.blogspot.co.id/2011/08/learning-achievement.html

Cresswell, J. W. (2012). Educational Research Design Planning, Conducting, and Evaluating Quanitative and Qualitative Research. Boston, USA: Pearson Education, Inc.

Hearing Loss. Types, Causes and Treatment. (2018, February 14). Retrieved from

http://googleweblight.com/?lite_url=http://www.hearingloss.org/content/types-causes-and treatment\&ei $=w 3 \mathrm{mt} x 8 \mathrm{eW} \& \mathrm{Ic}=\mathrm{en}=\mathrm{ID} \& \mathrm{~s}=1 \& \mathrm{~m} 15 \&$ host $=\mathrm{w} w \mathrm{w} \cdot$ google.com\&t5=1518601290\& sg=AOyes-QNxXYgfhvuaJbMyvatGKS78v9

Hoverkova, Veronika. (2012). Deaf Students Learning English as a Foreign Language. Masaryk University Brno.

Marschark, Mare et el. (2016). Don't Assume Deaf Students are Visual Learners. New York.

Merriam Webster Online Dictionary. Sign Language. MerriamWebster.com.MerriamWebster,n.d.web. 2018, February 15.

Perfetti C, Sandak R. Reading Optimally Builds on Spoken Languages: Implications for Deaf Readers. Journal of Deaf Studies and Deaf Education. 2000. Vol. 5 (Pg. 32 - 50)

Susanto, S., \& Nanda, D, S. (2018). Teaching and Learning English for Visually Impaired Students: An Ethnographic Case Study. English Review: Journal of English Education 7(1), 83-92. doi: $10.25134 /$ erjee.v7il.1530.

Wikipedia. Case Study. 2018, February 14). Retrieved from https://en.m.wikipedia.org/wik/CaseStudy

Wikipedia. Observation. (2018, February 14). Retrieved from https://en.m.wikipedia.org/wiki/observation 